DOI: $10.20472 /$ IAC.2019.049.039

TEA TSITLANADZE

Ivane Javakhishvili Tbilisi State University, Georgia

TEA KARCHAVA

Ivane Javakhishvili Tbilisi State University, Georgia

MURMAN PAPASHVILI

Ivane Javakhishvili Tbilisi State University, Georgia

ANDRO GOGOLADZE

Ivane Javakhishvili Tbilisi State University, Georgia

\title{
THE UNKNOWN NOTIFICATION OF XVI CENTURY FRENCH DIPLOMAT ABOUT OTTOMAN-PERSIAN RELATIONS AND GEORGIA
}

\begin{abstract}
:
The issue (which is the little part of joint scientific work, regards French communiques unknown so far for Georgian Historiography. They belong to French diplomat Juie who visited Constantinople in $\mathrm{XVI}$ century. The letters comprise quite interesting information. Their scientific value is determined by the fact that they belong to the person, who got notifications from a direct informer. The importance of the given documents grows, because there are very scanty contemporaneous sources depicting a domestic as well as a foreign political situation of Georgia of the 16thcentury. It is not doubtful that the author of the letters was well acquainted with the political peripeteias of the Ottoman-Iranian War, which began in 1578. It had a great importance for the history of Georgia, because the Georgians actively participated in the war against Ottomans on the basis of the "political Iranophilia". Therefore, a factual material delivered by the diplomat is very interesting for the consideration of a political orientation of the Georgian principalities of the last quarter of the 16th century. It indirectly indicates that political Iranophilia of the Kingdom of Kartli resulted from a real assessment of the international situation created in western Transcaucasia and Near East. Military, political and diplomatic relations with Iran enabled the King of Kartli (Simon I) to base his plans on the usage of Iran and to involve this country as well as the Kingdom of Kartli in anti-Ottoman coalition of the European states. Therefore, Christian Georgia was a connecting bridge for Iran, which looked for an ally in Catholic west (Spain, France, Italy, Germany). This fact enabled Simon I to carry out the policy in relation to the Europeans.

Three letters of French diplomat Juie reveal the Ottomans' preparation for a military expedition. These letters vividly depict how the Iranian government prevented the aggravation of the situation in the region. The position of the Georgian kings had a great significance in this respect. Therefore, these letters (together with the analogues Spanish and Italian sources) enable us to present a foreign policy of our country in the context of international relations and particularly, for the determination of the place occupied by Georgia in the Ottoman-Iranian diplomatic rivalry in western Europe.
\end{abstract}

\section{Keywords:}

Ottoman-Persian relations, Georgia, French notifications

**The research was carried out with the financial support of Shota Rustaveli National Foundation of Georgia [FR17_86] 